\title{
PERAN TEKNOLOGI, GURU DAN ORANG TUA DALAM \\ PEMBELAJARAN DARING DI MASA PANDEMI
}

\author{
(Suatu Kajian Tentang Efektifitas Pembelajaran Daring di Era New Normal Kasus Pandemi \\ COVID-19) \\ Aulia Riska Nugraheny \\ Mahasiswi Program Studi Pendidikan Ilmu Pengetahuan Sosial (PIPS) \\ FKIP Universitas Lambung Mangkurat Banjarmasin \\ Email: 1810128220024@mhs.ulm.ac.id
}

\begin{abstract}
ABSTRAK
Pembelajaran daring adalah salah satu kebijakan yang terpaksa diambil oleh pemerintah Indonesia sebagai upaya memutus mata rantai distribusi COVID-19 di masyarakat terutama di lingkungan sekolah. Kebijakan ini memaksakan adanya penjarakan sosial dalam pembelajaran antara guru dan peserta didik, yang semula metode pembelajarannya sebagian besar adalah tatap muka dan sekarang menjadi pembelajaran berbasis online/daring. Berkenaan dengan kebijakan pembelajaran daring ini tentunya semua pihak harus bekerjasama dengan baik agar pembelajaran daring menjadi kebijakan yang efektif sehingga hasil belajar peserta didik saat pembelajaran daring tidak kalah dari hasil belajar tatap muka di ruang kelas seperti pada saat pra-pandemi di negara kita. Teknologi sangat berperan penting bagi peserta didik dalam mengikuti pembelajaran daring, selain itu guru serta orang tua juga tidak kalah berperan dalam memberikan dukungan dan bimbingan terhadap usaha belajar anak. Hasil tinjauan dari penulisan ini menunjukan tingkat keefektifan pembelajaran daring dan penggunaan platform digital serta kendala apa saja yang terjadi saat pelaksanaan pembelajaran daring di rumah, menurut data yang diperoleh dari hasil review artikel ilmiah dan pendapat dari beberapa peserta didik, guru serta orang tua peserta didik.
\end{abstract}

Kata Kunci: Pembelajaran daring, COVID-19, kebijakan pemerintah.

\section{PENDAHULUAN}

Saat ini dunia sedang di gemparkan oleh pandemik COVID-19 yang berhasil menghilangkan banyak populasi manusia termasuk di negara kita Indonesia. Pemerintah Indonesia pun tidak ingin lamban dalam mengambil kebijakan-kebijakan baik dalam upaya pencegahan maupun penanganan kasus COVID-19 ini. Dunia pendidikan adalah bidang yang sangat terdampak oleh adanya pandemik COVID-19 setelah bidang ekonomi di negara kita. 
Penyebaran virus COVID-19 atau yang kerap disebut virus Corona ini ditemukan pertama kali persebarannya pada tanggal 2 Maret 2020, yaitu hari dimana Indonesia memiliki pasien pertama yang terjangkit COVID-19.

Diketahui per tanggal 23 Juli 2020 kemarin, penambahan kasus baru COVID-19 meningkat sebanyak 1.906 kasus. Dari penambahan kasus tersebut, menyebabkan saat ini ada 93.657 kasus COVID-19 di Indonesia secara keseluruhan, 52.164 pasien sembuh dan 4.576 total yang meninggal dunia (covid19.go.id, 2020). Penambahan ribuan kasus dalam kurun waktu 24 jam tersebut tentunya bukan suatu hal yang bisa di anggap wajar, namun dari angka pernambahan ini menunjukan bahwa masih kurang tegasnya otoritas, peraturan dan anjuran yang diberikan oleh pemerintah serta kurangnya kedisiplinan dan kepedulian masyarakat Indonesia dalam menjalankan protokol kesehatan ketika beraktivitas di luar rumah menyambut era new normal saat ini.

Pemerintah Indonesia mengeluarkan kebijakan pembelajaran daring sebagai upaya pencegahan adanya transmisi persebaran COVID-19 di sekolah terutama di ruang kelas. Maka dari itu, kebijakan ini membuat adanya pembatasan sosial dan pengenyampingan sistem pembelajaran tatap muka dan sementara akan digantikan dengan pembelajaran daring lewat beberapa platform digital yang telah dipilih oleh pihak guru dan masing-masing sekolah. Dalam menjalankan kebijakan yang tentunya membawa wajah baru bagi pendidikan Indonesia ini tentunya masih terdapat banyak kendala dalam pelaksanaannya, karena tidak semua sekolah yang pernah melakukan sistem pembelajaran daring ini, maka wajar baik pihak guru, peserta didik maupun orang tua/wali peserta didik mendapatkan kendala menghadapi sistem baru ini. Berdasarkan hal-hal di atas, penulisan artikel ini menjadi sangat penting agar kita dapat mengetahui bagaimana sebenarnya peran teknologi, guru dan orang tua serta kesiapan para peserta didik dalam menjalani sistem pembelajaran daring.

\section{HASIL DAN PEMBAHASAN}

Sebelum pandemi COVID-19 masuk ke Indonesia, sistem pembelajaran daring memang sempat digalakan pemerintah dan beberapa sekolah terutama sekolah-sekolah di Ibu Kota telah melaksanakan sistem pembelajaran berbasis online. Namun, ketika pandemi masuk ke Indonesia ini, pemerintah terpaksa mengambil kebijakan bahwa semua sekolah wajib melakukan kegiatan belajar mengajar secara daring dan non tatap muka. Kebijakan ini diambil pemerintah sebagai 
upaya pencegahan semakin bertambahnya distribusi kasus positif COVID-19 secara massif yang tentunya meresahkan masyarakat Indonesia (Syaharuddin, S., 2020). Bercermin dari kebijakan ini, tentunya ketidakmerataan kualitas pendidikan Indonesia menjadi kendala utama penerapan kebijakan ini, karena kesiapan peserta didik yang bersekolah di perkotaan berbeda sekali dengan peserta didik yang bersekolah di daerah pelosok maupun berdasar latar belakang ekonomi sang peserta didik.

Teknologi merupakan hal yang terpenting dalam pembelajaran daring, teknologi tersebut diantaranya bisa berupa smartphone, laptop dan benda pendukung lainnya. Smartphone/gadget adalah hal yang paling umum digunakan peserta didik daripada laptop, karena lebih praktis dan banyak fitur canggihnya (Subiyakto, B., Susanto, H., \& Akmal, H., 2019). Pembelajaran daring yang diselenggarakan oleh kebanyakan guru dan siswa juga menggunakan beberapa platform digital yang menarik dan tentunya membantu sekali untuk meningkatkan keefektifan belajar peserta didik selama masa pandemi ini. Beberapa platform digital tersebut yaitu Google Class Room, E-Learning, Edmodo, Zoom dan Google Meet. Yang paling terkenal yaitu Google Class Room dan Google Meet karena terkenal mudak diakses, tampilannya tidak membingungkan dan tentunya menggunakan data internet yang lebih hemat dari aplikasi diskusi dan video conference lainnya. Penggunaan teknologi sebagai sumber informasi, sumber belajar, sistem dan kualitas layanan telah memberikan dampak positif pada masa pandemi ini yang sebagian besarnya bermanfaat bagi proses pembelajaran daring (Abbas, E. W., 2019).

Meskipun begitu, kita tidak bisa menutup mata bahwa masih banyak peserta didik yang memiliki latar belakang ekonomi menengah ke bawah dan tidak memiliki teknologi pendukung seperti laptop ataupun gawai/smartphone. Selain itu nasib peserta didik yang bertempat tinggal di daerah pelosok juga dikhawatirkan, karena tentunya fasilitas jaringan internet yang belum memadai daya jangkaunya juga tingkat pemahaman peserta didik masih rendah tentang penggunan aplikasi belajar secara online. Selain memakai aplikasi khas untuk kegiatan pembelajaran, guru dan peserta didik juga biasanya menggunakan aplikasi WhatsApp karena dinilai lebih mudah. Dari sekian daftar aplikasi yang sudah disebutkan, aplikasi WhatsApp lah yang penggunaannya bisa lebih mudah diakses hingga ke pelosok desa, asal jaringan internetnya ada maka aplikasi ini tidak memerlukan loading yang lamban dan tidak memakan banyak kuota.

Kendala di bidang penggunaan teknologi ini tidak hanya dirasakan oleh peserta didik saja, melainkan juga dirasakan oleh guru. Menurut Norma (27), Seorang pendidik di SDN Sungai 
Miai 5 Banjarmasin, dirinya memiliki beberapa kendala dalam memberikan pembelajaran menggunakan aplikasi belajar online. Beberapa kendala tersebut yaitu pengoprasian aplikasi, sulitnya memusatkan perhatian dan fokus belajar peserta didik dan adanya tantangan dalam menjaga motivasi belajar peserta didik, dari segi evaluasi pun Norma takut keliru dalam pemberian nilai karena kurang mengetahui apakah para peserta didik telah paham dengan materi ajarnya dan sebagian besar penilaian didasarkan dari sikap dan keaktifan peserta didik ketika pembelajaran.

Pada pembelajaran tatap muka, guru lebih leluasa menyampaikan materi ajar dan menilai motivasi belajar para peserta didiknya. Di masa pandemi yang pembelajarannya serba online, guru diharapkan dapat lebih kreatif dan inovatif untuk membuat bahan ajar yang menarik minat dan semangat belajar peserta didik, selain itu guru juga dituntut untuk cermat dalam penguasaan ilmu pengetahuan dan teknologi (Syaharuddin, S., \& Mutiani, M., 2020). Tidak usah jauh-jauh, misalnya guru dapat menjadikan situasi pandemi COVID-19 sebagai sumber belajar. Misalnya sebagai sumber belajar mata pelajaran IPS, guru membuat strategi jitu yang dapat membuat peserta didik tertarik, ingin mengetahui lebih jauh, sadar dan peduli terhadap bahaya COVID-19 bagi masyarakat.

Peserta didik bisa diarahkan untuk mencari tahu tentang COVID-19 melalui berbagai sumber platform pencarian online. Guru juga dapat memasukan kearifan lokal atau biografi tokoh terkenal di daerahnya, misalnya pada daerah Kalimantan Selatan diambilah contoh biografi Nadjmi Adhani, Walikota Banjarbaru sebagai sumber pembelajaran terutama untuk mata kuliah IPS. Peserta didik bisa membaca biografi yang diberikan oleh guru lalu menelaahnya dan menemukan nilai-nilai kepemimpinan apa saja yang bisa dijadikan sebagai panutan untuk ditiru, pengambilan sumber belajar seperti ini membuat peserta didik dengan mudah mengetahui, memahami dan menarik rasa ingin tahu peserta didik terhadap pemimpin di daerahnya sendiri (Janah, W. A., Abbas, E. W., \& Mutiani, M., 2020).

Tidak hanya mengambil contoh dari gaya kepemimpinan Nadjmi Ridhani, kita juga dapat mengambil contoh tokoh Rudy Resnawan, yang memiliki nilai kepemimpinan yang religius, disiplin, inovatif dan lain sebagainya (Wahyuningsih, S., Abbas, E. W., \& Mutiani, M., 2020). Selain itu peserta didik juga bisa dikenalkan dengan kebudayaan khas daerahnya, agar peserta didik lebih mengetahui dan bangga dengan produk-produk dari kebudayaannya sendiri. Mengambil contoh, misalnya peserta didik diberikan materi ajar tentang bagaimana produksi topi 
purun di Kampung purun dan hubungannya dengan konsep ekonomi di dalam pembelajaran IPS, intinya guru harus benar-benar berinovasi dalam membuat atau mencari sumber belajar bagi peserta didik (Lestari, J. A., Abbas. E. W., \& Mutiani., 2020).

Di sisi lain, para orang tua juga sangat berperan sebagai pembimbing sekaligus motivator bagi anak-anaknya saat belajar di rumah. Kendala yang dirasakan oleh orang tua peserta didik yaitu seperti yang dirasakan oleh Mahrita (47), menurutnya tanggung jawab sebagai pengajar pengganti di rumah saat pandemi ini tidak bisa dianggap remeh, karena harus membagi waktu mengerjakan pekerjaan rumah dan membimbing anak saat pembelajaran online. Mengapa orang tua sulit dalam mengganti peran guru yaitu karena profesi guru itu memerlukan keahlian khusus dan tidak dapat dilakukan oleh sembarang orang yang basic-nya tidak dari bidang pendidikan keguruan (Subiyakto, B., \& Akmal, H., 2020). Kendala lain yang juga bisa dirasakan menurutnya yaitu, beliau juga tidak terlalu mahir mengoprasikan aplikasi belajar pembelajaran daring. Namun, di balik hal itu, positifnya beliau dapat lebih banyak menghabiskan waktu untuk membimbing tumbuh kembang anak sambil belajar di rumah dan lebih banyak waktu berkomunikasi dengan anak, karena pada masa sebelum pandemic tersebut anak-anak bersekolah hingga enam jam sehari.

Maka dari itu, adanya pembelajaran daring dampak dari pandemi COVID-19 ini tidak hanya memberikan kesan merugikan pada proses pembelajaran, melainkan juga menyiratkan kesan yang baik sehingga dapat mengubah wajah pendidikan Indonesia menjadi lebih modern. Kemajuan pendidikan Indonesia yang lebih adil dan merata ini terlihat sekali perbedaannya dengan wajah pendidikan Indonesia pada masa kolonial, kaum yang bisa mengenyam bangku pendidikan hanyalah kaum menengah keatas dan kurikulumnya pun standar seperti membaca, menulis, berhitung, menggambar, menyanyi, mengenal ilmu bumi dan lain-lainnya yang sangat jauh perkembangannya dengan sekarang ini (Syaharuddin, S., \& Susanto, H., 2019). Kemudian, hal yang perlu diperhatikan yaitu agar guru dan orang tua dapat bekerjasama untuk menjaga motivasi belajar dan meminimalisir stress belajar pada peserta didik. Nah, cara mengurangi stress biasanya bisa dengan membuat status-status yang berisi keluhan hidup di media sosial, ada baiknya hal itu dirujuk pada hal yang lebih bermanfaat misalnya menulis pemikiran yang inovatif sebagai cara menyikapi hal-hal yang kita resahkan (Abbas, E. W., 2020). Hal itu bisa dilakukan melalui cara pemberian tugas-tugas yang sesuai dengan jenjang pendidikan dan dapat dipahami peserta didik serta pengelolaan suasana lingkungan belajar yang baik. Maka dari itu 
baik Teknologi, guru dan orang tua sangat berperan dalam proses pembelajaran daring di masa pandemi ini.

\section{DAFTAR PUSTAKA}


Abbas, E. W. (2019). Managing Information System By Integrating Information System Success Model And The Unified Theory Of Acceptance And Usage Of Technology. Polish Journal Of Management Studies. 20(1).

Abbas, E. W. (2020). Menulis di Era Covid-19: Memanage Trauma Psikologis Menghindari Psikosomatis.

Gugus Tugas Percepatan Penanganan COVID-19 Indonesia. (2020). Data COVID-19 Global dan Indonesia. https://covid19.go.id/.

Janah, W. A., Abbas, E. W., \& Mutiani, M. (2020). The Contribution of Leadership Value of Nadjmi Adhani as a Learning Resources on Social Studies. The Inovation of Social Studies Journal. 1(2). 188-196.

Lestari, J. A., Abbas. E. W., \& Mutiani. (2020). Production Activities of Kampung Purun Banjarbaru as a Learning Resource on Social Studies. The Inovation of Social Studies Journal. 1(2). 139-149.

Subiyakto, B., Susanto, H., \& Akmal, H. (2019). Media Pembelajaran Sejarah Era Teknologi Informasi. Banjarmasin: Program Studi Pendidikan Sejarah, ULM.

Susanto, H., Subiyakto, B., \& Akmal, H. (2020). Profesi Keguruan.Banjarmasin: Program Studi Pendidikan Sejarah, ULM.

Syaharuddin, S. (2020). Pembelajaran Masa Pandemi: Dari Konvensional Ke Daring.

Syaharuddin, S., \& Susanto, H. (2019). Sejarah Pendidikan Indonesia (Era Pra Kolonialisme. Nusantara Sampai Reformasi). Banjarmasin: Program Studi Pendidikan Sejarah, ULM.

Syaharuddin, S., \& Mutiani, M. (2020). Strategi Pembelajaran IPS: Konsep dan Aplikasi. Banjarmasin: Program Studi Pendidikan IPS, ULM.

Wahyuningsih, S., Abbas, E. W., \& Mutiani, M. (2020). Implementation of Leadership Value Of Rudi Resnawan as a Learning Resources on Social Studies. The Inovation of Social Studies Journal. 1(2). 169-177. 